Hal. 378 - 389

\title{
PENERAPAN CORPORATE GOVERNANCE DENGAN MENGGUNAKAN BALANCE SCORECARD PADA BANK MANDIRI JEMBER
}

\author{
Ponti Primastuti Aulia Nugraheni \\ Jurusan Akuntansi, Fakultas Ekonomi, Universitas Jember \\ pontiaulia@gmail.com
}

\begin{abstract}
Good corporate governance is a barometer of for a company accountability. A poor corporate governance implementation is presumed as one of the causes of various corporate financial business scandals. Banking companies deal directly with the provision of goods and services to meet the wants and needs of the community. In this case, the community is the customer that must be served well in order to meet their satisfaction by applying a good organizational management mindset to improve the customer (community) satisfaction. Applying the Balanced Scorecard (BSC) approach, banks will be able to explain their mission to the community, identify the indicators of public satisfaction more transparently, objective, and measurable, and identify the work processes and the quality of human resources needed to achieve their mission and vision. In the implementation process, the banking activities will produce a community-oriented strategic management system.
\end{abstract}

Keywords: Corporate Governance, Bank, BSC.

\begin{abstract}
Abstrak: Tata kelola perusahaan yang baik (good corporate governance) merupakan barometer akuntabilitas suatu perusahaan. Lemahnya penerapan corporate governance diduga sebagai salah satu pemicu terjadinya berbagai skandal keuangan bisnis perusahaan. Perbankan berhubungan langsung dengan penyediaan barang dan jasa untuk memenuhi keinginan dan kebutuhan masyarakat. Dalam hal ini masyarakat merupakan pelanggan yang harus dilayani dengan baik dalam rangka memenuhi kepuasan mereke sehingga perlu diterapkan pola pikir pengelolaan organisasi yang baik tentang bagaimana meningkatkan kepuasan pelanggan (masyarakat). Dengan pendekatan BSC, perbankan akan mampu menjelaskan misinya kepada masyarakat, dapat mengidentifikasi indikator kepuasan masyarakat secara lebih transparan, objektif, dan terukur, serta mampu mengidentifikasi proses kerja dan kualitas sumber daya manusia yang dibutuhkan dalam mencapai misi dan visinya. Dalam proses implementasinya, kegiatan yang di lakukan oleh perbankan akan dapat menghasilkan suatu sistem manajemen strategik yang berorientasi pada masyarakat.
\end{abstract}

Kata Kunci: Corporate Governance, Bank,BSC.

\section{PENDAHULUAN}

Timbulnya kasus disalah satu perbankan beberapa waktu yang lalu membuat kita semua sempat berpendapat apakah manajemen telah mengimplementasikan tata kelola bank dengan baik atau tidak. Hal ini disebabkan karena adanya indikasi kecurangan yang dilakukan oleh pihak manajemen bank untuk mencari keuntungan diri sendiri. Menurut Sutojo dan Aldridge (2008:7) menyatakan bahwa corporate governance dapat membantu 
board of director mengarahkan dan mengendalikan kegiatan bisnis perusahaan sesuai dengan tujuan yang diinginkan pemiliknya. Jadi, jika tata kelola perusahaan yang dibuat dilanggar hanya untuk memenuhi kepentingan diri sendiri merupakan suatu bentuk kerugian. Bank Indonesia (BI) mengakui bahwa salah satu bank tersebut mengalami masalah dan kolaps karena kesalahan pemilik perusahaan. Keadaan seperti ini dapat menimbulkan keraguan mengenai efektifitas corporate governance yang dimiliki perusahaan sebagai sistem pengendalian. Sistem pengendalian yang baik ditunjang pula dengan keseriusan manajemen untuk mengimplementasikannyaa secara benar dan dapat membantu perusahaan dalam mencegah maupun menyelesaikan masalah yang ada.

Pada saat ini banyak yang berpikir bahwa tata kelola perusahaan yang baik (good corporate governance) menjadi suatu kebutuhan sebagai barometer akuntanbilitas dari suatu perusahaan. Lemahnya penerapan corporate governance diduga sebagai salah satu pemicu terjadinya berbagai skandal keuangan bisnis perusahaan. Kasus Bank Century sebagai contoh bahwa banyak pihak menduga kasus ini akibat kecurangan yang dilakukan pihak internal bank dengan pihak lain. Ciri utama dari lemahnya corporate governance adalah tindakan mementingkan diri sendiri di pihak manajer. Hal ini bisa saja sistem pengendalian yang mereka buat memang lemah dengan tujuan agar dapat melakukan kecurangan, yang pada akhirnya melemahkan nilai perusahaan. Maka dari itu penerapan balanced scorecard dinilai dapat membantu perusahaan untuk melakukan pengukuran kinerja secara lebih komprehensif dan akurat.

Pada umumnya pengendalian yang disusun dan dilakukan oleh pihak perbankan berjalan sangat ketat karena jika terjadi kecurangan akan berdampak pada pihak perbankan dengan nilai kerugian yang tidak sedikit. Perusahaan dan bank dengan skala kecil seakan menganggap corporate governance hanya sebagai formalitas saja karena yang terpenting bagi mereka adalah perusahaan dapat menghasilkan profit yang besar sehingga perusahaan akan tumbuh dan berkembang dengan cepat yang pada akhirnya menyebabkan nilai perusahaan menjadi tinggi, oleh sebab itu dikenalkannya dengan konsep balance scorecard (BSC) sebagai suatu sistem pengukuran kinerja yang dapat digunakan sebagai alat pengendalian, analisis dan merevisi strategi organisasi yang berorientasi pada profit.

\section{Hasil dan Pembahasan}

\section{Corporate Governance}

Corporate governance merupakan sebuah kumpulan hukum, peraturan dan kaidahkaidah yang wajib terpenuhi untuk mendorong kinerja perusahaan dalam menghasilkan nilai ekonomi jangka panjang yang berkesinambungan bagi para pemegang saham maupun masyarakat sekitar secara keseluruhan dan bekerja secara efisien (World Bank dalam 
Tunggal, 2008 : 4). Corporate governance adalah suatu sistem pengendalian internal perusahaan yang memiliki tujuan utama mengelola risiko yang signifikan guna memenuhi tujuan bisnisnya melalui pengamanan aset perusahaan dan meningkatkan nilai investasi pemegang saham dalam jangka panjang

Corporate governance merupakan suatu sistem yang mengatur dan mengendalikan perusahaan yang diharapkan dapat memberikan dan meningkatkan nilai perusahaan kepada para pemegang saham (Siallagan dan Machfoedz, 2006). Organization for Economic Cooperation and Development (OECD) mendefinisikan Corporate governance sebagai sekumpulan hubungan antara pihak manajemen perusahaan, board, pemegang saham, dan pihak lain yang mempunyai kepentingan dengan perusahaan. Corporate governance juga mensyaratkan adanya struktur perangkat untuk mencapai tujuan dan pengawasan atas kinerja

Menurut keputusan Menteri Badan Usaha Milik Negara Nomor KEP-117/MMBU/2002, Corporate governance adalah suatu proses dari struktur yang digunakan oleh BUMN untuk meningkatkan keberhasilan usaha dan akuntabilitas perusahaan guna mewujudkan nilai pemegang saham dalam jangka panjang dengan tetap memperhatikan kepentingan stakeholder lainnya, berdasarkan peraturan perundang-undangan dan nilainilai etika. Dari beberapa definisi diatas dapat disimpulkan bahwa Corporate governance adalah mengenai suatu sistem, proses dan seperangkat peraturan yang mengatur hubungan antara berbagai pihak yang berkepentingan dengan manajemen perusahaan. Demi tercapainya tujuan yang menguntungkan bagi masing-masing pihak. Penerapan good corporate governance dapat memberikan dan meningkatkan nilai perusahaan melalui investasi para pemegang saham.

\section{Prinsip-Prinsip Corporate Governance}

Sejak beberapa tahun terakhir ini masyarakat bisnis mulai menyadari bahwa good corporate governance dapat memberikan kontribusi yang signifikan terhadap stabilitas perkembangan pasar modal, iklim investasi dan pertumbuhan ekonomi di suatu negara. Corporate governance memilik enam prinsip yang diterbitkan oleh OECD untuk mewujudkan Corporate governance sebagai bentuk pengelolaan perusahaan yang baik, antara lain :

1. Landasan hukum yang diperlukan untuk menjamin penerapa good corporate governance secara efektif. Landasan hukum ini antara lain berupa penciptaan:
a. Undang-undang tentang perseroan terbatas.
b. Undang-undang perburuhan.
c. Undang-undang tentang perbankan.
d. Ketentuan tentang standar akuntansi keuangan dan standar audit. 
e. Syarat dan prosedur pendaftaran saham di bursa efek.

2. Hak pemegang saham dan fungsi pokok kepemilikan perusahaan.

Sebagai contoh hak pemegang saham perusahaan publik adalah menjual kembali atau memindah tangankan saham yang mereka miliki.

3. Perlakuan yang adil terhadap para pemegang saham.

Perusahaan wajib menjamin perlakuan yang adil terhadap semua pemegang saham perusahaan, termasuk pemegang saham minoritas maupun asing.

4. Peranan stakeholder dalam Corporate governance.

Keberhasilan operasi bisnis perusahaan nantinya akan ditentukan oleh hasil kerjasama dari anggota stakeholder.

5. Prinsip pengungkapan informasi perusahaan secara transparan.

Perusahaan wajib melaporkan kepada pemegang saham secara akurat, transparan dan tepat waktu, kondisi keuangan, perubahan kepemilikan, dan hal-hal lainnya yang dapat mempengaruhi kelangsungan hidup perusahaan.

6. Tanggung jawab dewan pengurus.

Bertanggung jawab atas kepatuhan perusahaan yang dikelola terhadap undangundang atau ketentuan hukum yang berlaku, termasuk undang-undang tentang perpajakan, perburuhan, persaingan, lingkungan hidup dan keselamatan kerja.

Prinsip-prinsip diatas berkaitan dengan beberapa harapan stakeholders yang dapat digunakan sebagai bahan acuan internasional bagi para investor, perusahaan dan para stakeholders perusahaan guna mencapai tujuan yang diharapkan. Selain prinsipprinsip yang dikemukan diatas terdapat pula beberapa prinsip yang sesuai dengan Keputusan Menteri Badan Usaha Milik Negara Nomor KEP-117/M-MBU/2002, antara lain :

1. Transparansi

Keterbukaan dalam melaksanakan proses pengambilan keputusan dan pengungkapan informasi yang relevan mengenai perusahaan.

2. Pengungkapan

Penyajian informasi kepada para pemangku kepentingan, baik diminta maupun tidak diminta, mengenai hal-hal yang berkenaan dengan kinerja operasional, keuangan, dan risiko usaha perusahaan.

3. Kemandirian

Suatu keadaan dimana perusahaan yang dikelola secara profesional tanpa konflik kepentingan dan pengaruh atau tekanan dari pihak manapun yang tidak sesuai dengan undang-undang yang berlaku dan prinsip-prinsip korporasi yang sehat.

4. Akuntabilitas 
Kejelasan fungsi, pelaksanaan, serta pertanggung jawaban manajemen perusahaan sehingga pengelola perusahaan terlaksana secara efektif dan ekonomis.

5. Pertanggung jawaban

Kesesuaian pengelolaan perusahaan terhadap peraturan perundang-undangan yang berlaku dan prinsip-prinsip korporasi yang sehat.

6. Kewajaran

Keadilan dan kesetaraan dalam hak-hak pemangku kepentingan yang timbul sebagai akibat dari perjanjian dan peraturan perundang-undangan yang berlaku.

Konsep Corporate governance timbul sebagai upaya untuk mencegah atau mengatasi perilaku manajemen yang mementingkan kepentingan sendiri dengan menciptakan suatu mekanisme kontrol bagi stakeholders. Corporate governance dapat menciptakan pengelolaan perusahaan yang lebih demokratis, karena melibatkan banyak pertisipasi dari berbagai kepentingan dan lebih accountable karena terdapat sistem yang nantinya akan mengatur dan meminta pertanggung jawaban atas setiap tindakan dan lebih transparan.

\section{Balanced Scorecard}

Balanced scorecard merupakan contemporary management tool yang digunakan untuk mendongkrak kemampuan organisasi dalam melipat gandakan kinerja keuangan (Mulyadi, 2001). Kaplan dan Norton (2000: 25-29) menjelaskan ada empat perspektif dalam $B S C$, yaitu sebagai berikut :

1. Perspektif Keuangan (Finansial)

Pemahaman perspektif finansial dalam manajemen $B S C$ sangat penting karena keberlangsungan suatu unit bisnis strategis sangat tergantung pada posisi dan kekuatan finansial. Berkaitan dengan hal ini, berbagai rasio finansial dapat diterapkan dalam pengukuran strategis untuk perspektif finansial. Manajemen bisnis harus memperhatikan agar semua analisis rasio finansial menunjukkan hasil yang baik. Hal itu penting karena manajemen harus mampu membayar utang, baik kepada kreditor jangka pendek maupun kreditor jangka panjang, termasuk kemampuan menghasilkan keuntungan untuk pemegang saham.

2. Perspektif Customer

Dalam perspektif pelanggan, perusahaan harus mengidentifikasikan pelanggan dan segmen pasar di mana mereka akan berkompetisi. Elemen yang paling penting dalam suatu bisnis adalah kebutuhan pelanggan, sehingga kebutuhan pelanggan harus diidentifikasi secara tepat. Misalnya demografi, aktivitas umum pembeli, posisi atau tanggung jawab pembeli, dan karakteristik pribadi pembeli. Di samping itu, 
konsep segmentasi pasar juga penting untuk diketahui karena akan bermanfaat bagi penilaian pasar dan penetapan strategi memasuki pasar (strategi pemasaran). Selanjutnya mengidentifikasi kekuatan kompetitif dan dilakukan analisis agar dapat diketahui secara dan pasar realistik dapat diidentifikasi.

3. Perspektif Proses Bisnis Internal

Dalam perspektif proses bisnis internal, manajer harus mengidentifikasi prosesproses yang paling kritis untuk mencapai tujuan peningkatan nilai bagi pelanggan (perspektif pelanggan) dan tujuan peningkatan nilai bagi pemegang saham (perspektif finansial). Banyak organisasi memfokuskan untuk melakukan peningkatan proses - proses operasional. Yang bisa digunakan untuk BSC adalah model rantai nilai proses bisnis internal yang terdiri atas tiga komponen utama, yaitu sebagai berikut :

a. Proses inovasi, mengidentifikasi kebutuhan pelanggan masa kini dan masa mendatang serta mengembangkan solusi baru untuk kebutuhan pelanggan.

b. Proses operasional, meng identifikasi sumber-sumber pemborosan dalm proses operasional serta mengembangkan solusi masalah yang terdapat dalam proses operasional itu untuk meningkat kan efisiensi produksi, meningkatkan kualitas produk dan proses, memperpendek siklus waktu sehingga meningkatkan penyerahan produk berkualitas secara tepat waktu, dan lain-lain.

c. Proses pelayanan, berkaitan dengan pelayanan kepada pelanggan, seperti pelayanan purnajual, menyelesaikan masalah yang timbul pada pelanggan dalam kesempatan pertama secara cepat, melakukan tindak lanjut secara proaktif dan tepat waktu, memberikan sentuhan pribadi (personal touch), dan lain-lain.

4. Pespektif Pertumbuhan dan Pembelajaran

Perspektif keempat dalam BSC adalah mengembangkan tujuan dan ukuran-ukuran yang mengendalikan pembelajaran dan pertumbuhan organisasi. Tujuan-tujuan yang ditetapkan dalam perspektif finansial, pelanggan, dan proses bisnis internal mengidentifikasi yang mana organisasi harus unggul untuk mencapai terobosan kinerja, sementara itu tujuan dalam perspektif ini memberikan infrastruktur yang memungkinkan tujuan-tujuan ambisius dalam ketiga perspektif itu tercapai. Tujuantujuan dalam perspektif ini merupakan pengendali untuk mencapai keunggulan outcome ketiga perspektif (finansial, pelanggan, dan proses bisnis internal). Terdapat tiga kategori yang sangat penting dalam perspektif pembelajaran dan pertumbuhan, yaitu (1) kompetensi karyawan, (2) infrastruktur teknologi, dan (3) kultur perusahaan. 
Agar suatu manajemen strategik dapat berjalan dengan baik maka visi dan strategi organisasi harus sesuai dengan empat perspektif yaitu perspektif keuangan, perspektif customer, perspektif proses bisnis internal, dan perspektif pertumbuhan dan pembelajaran. Setiap perspektif tersebut harus ditunjukkan tujuan (objectives), ukuran-ukuran (measures), kinerja yang digunakan, target yang akan dicapai, dan inisiatif strategik yang harus dilakukan untuk mencapai target yang telah ditetapkan sekaligus untuk mencapai misi organisasi. Kemampuan organisasi untuk dapat men-translate visi dan misi ke dalam tindakan nyata sangat menentukan keberhasilan implementasi strategi tersebut.

BSC memiliki empat manfaat yaitu :

1. Implementasi strategi dengan mengarahkan perhatian manajer pada faktor kritis sukses (critical success factor) yang relevan dan cara mencapainya.

2. Menentukan sifat dan arah perubahan yang harus dilakukan dalam pengimplementasian strategi.

3. Menjadi dasar yang objektif bagi perusahaan dalam penilaian kinerja dan penentuan kompensasi manajemen.

4. Menjadi suatu kerangka kerja bagi seluruh personel perusahaan dalam melakukan tindakan-tindakan yang mengarah pada pencapaian tujuan.

BSC juga memiliki enam tahapan dalam membangun BSC yaitu sebagai berikut :

1. Menilai fondasi organisasi yang meliputi analisis kekuatan, kelemahan, kesempatan, dan ancaman organisasi yang dapat dilakukan dengan menggunakan analisis SWOT atau benchmarking terhadap organisasi lainnya.

2. Membangun strategi bisnis, Dalam membangun strategi, organisasi harus mempertimbangkan pendekatan apa saja yang bisa digunakan untuk menjalankan strategi tersebut, termasuk di dalamnya apakah strategi tersebut bisa dijalankan, berapa banyak sumber daya yang dibutuh kan, dan apakah strategi tersebut mendukung pencapaian misi organisasi.

3. Membuat tujuan organisasi, Tujuan organisasi merupakan gambaran aktivitasaktivitas yang harus dilakukan oleh organisasi dan waktu yang dibutuhkan untuk mencapainya.

4. Membuat peta strategi (strategic map) bagi strategi bisnis, peta strategi atau strategic map dapat dibangun dengan menghubungkan strategi dan tujuan ke dalam empat perspektif dari unit-unit dengan menggunakan hubungan sebab-akibat (cause-effect relationship).

5. Menentukan ukuran kinerja, ukuran atau indikator kinerja harus ditetapkan sesuai dengan tujuan-tujuan strategis. Dalam setiap perspektif dinyatakan tujuan-tujuan strategis yang ingin dicapai. Untuk setiap tujuan strategis harus ditetapkan paling sedikit satu ukuran kinerja. 
6. Menyusun inisiatif, Inisiatif adalah program-program yang harus dilakukan untuk memenuhi salah satu atau berbagai tujuan strategis. Inisiatif ditetapkan berdasarkan target, yaitu tingkat kinerja yang diinginkan.

\section{Penerapan Corporate Governance dengan Metode Balanced Scorecard}

Salah satu dasar penilaian prestasi suatu perusahaan dapat dilihat dari kemampuan perusahaan dalam menghasilkan laba. Nilai perusahaan merupakan ukuran keberhasilan atas pelaksanaan fungsi-fungsi keuangan. Tujuan dari menganalisis laporan keuangan perusahaan, yaitu untuk menilai atau mengevaluasi suatu kinerja khususnya manajemen perusahaan dalam suatu periode akuntansi, serta menentukan strategi apa yang harus diterapkan pada periode berikutnya jika tujuan perusahaan sebelumnya telah tercapai. Corporate governance merupakan mekanisme pengendalian untuk mengatur dan mengelola bisnis dengan maksud untuk meningkatkan kemakmuran dan akuntabilitas perusahaan, yang tujuan akhirnya untuk mewujudkan shareholders value (Lastanti, 2005; dalam Ramadhani, 2008).

Penerapan prinsip-prinsip corporate governance yang didukung dengan regulasi yang baik, diharapkan akan mencegah berbagai bentuk ketidakjujuran dalam penyajian laporan keuangan. Salah satu prinsip corporate governance yang utama adalah transparansi, menunjukkan bahwa untuk dapat menghasilkan kinerja perusahaan yang baik dalam pengelolaan perusahaan harus menerapkan pilar-pilar good corporate governance yang salah satu pilar utamanya adalah transparansi (Hastuti, 2005). Transparansi diproksikan oleh pengungkapan laporan keuangan. Hal penting yang menarik untuk dibahas yaitu pengungkapan laporan keuangan yang digunakan oleh Hastuti (2005) adalah pengungkapan yang bersifat mandatory. Seharusnya indeks wallace menghasilkan nilai 1 untuk semua perusahaan sampel karena mandatory disclosure adalah pengungkapan laporan keuangan minimal yang harus dilakukan oleh perusahaan yang go public di pasar modal Indonesia sebagaimana disyaratkan oleh Bapepam. Standar mandotory disclosure yang harus disajikan oleh emiten yang dipakai dalam penelitian ini merupakan standar yang dikeluarkan tahun 1999 (standar terbaru). Tetapi dari hasil penelitian ini meskipun mandatory disclosure tetapi tidak semua item dalam mandatory disclosure dipenuhi oleh emiten. Hal ini mengindikasikan dalam realita Bapepam belum tegas dalam memberlakukan konsep disclosure yang merupakan pilar dari good corporate governance untuk para emiten yang berdagang di bursa pasar modal sehingga menyebabkan masih terjadinya kebocoran pelaksanaan good corporate governance di Indonesia.

Pada dasarnya BSC merupakan sistem yang dapat membantu pengukuran kinerja yang mencoba mengubah misi dan strategi organisasi menjadi tujuan dan ukuran-ukuran yang lebih berwujud. Ukuran finansial dan nonfinansial yang dirumuskan dalam perspektif 
BSC sebenarnya adalah derivasi (penurunan) dari visi dan strategi organisasi. Dengan demikian, hasil pengukuran dengan BSC ini mampu menjawab pertanyaan tentang seberapa besar tingkat pencapaian organisasi atas visi dan strategi yang telah ditetapkan.

Pada organisasi penyedia layanan publik, tujuan utama pengukuran kinerjanya adalah untuk mengevaluasi keefektifan layanan jasa yang diberikan kepada masyarakat. Oleh karena itu, kepuasan pelanggan menjadi lebih penting daripada sekadar keuntungan. Trend pengukuran kinerja organisasi layanan publik saat ini adalah pengukuran kinerja berbasis out come daripada sekadar ukuran-ukuran proses. Artinya, kinerja organisasi ini sebenarnya tidak terletak pada proses mengolah inputmenjadi output, tetapi justru penilaian terhadap seberapa bermanfaat dan sesuai output tersebut memenuhi harapan dan kebutuhan masyarakat. Bahkan, auditing konvensional yang semula berfokus pada ukuran proses mulai bergeser ke arah pengukuran outcome.

Outcome merupakan segala sesuatu yang mencerminkan berfungsi nya output kegiatan pada jangka menengah bagi masyarakat pengguna jasa organisasi publik. Outcome suatu organisasi didasar kan atas keberhasilan pencapaian visi bukan pada keberhasilan meningkatkan profitabilitas. Jadifinal outcomeorganisasi publik bukan ukuran finansial melainkan lebih cenderung pada ukuran pelanggan. Keberhasilan instansi pemerintah seharus nya diukur dari bagaimana mereka bisa memenuhi apa yang dibutuhkan masyarakat dan stakeholders lain yang telah menyediakan sumber daya.

Pada dasarnya manajemen kinerja dan penilaian kualitas tidak ditujukan untuk memperbaiki pelayanan, tetapi hanya membantu mengidentifikasi area yang perlu diperbaiki sehingga bisa lebih fokus. BSC digunakan sebagai alat pendukung untuk komunikasi, motivasi, dan mengevaluasi strategi organisasi utama. Dengan BSC ini manajemen bisa lebih efektif, tetapi BSC tidak menjamin manajemen efektif. Hal ini bisa terjadi jika manajemen tidak tepat men-derived visi dan strategi organisasi dalam ukuranukuran kinerja BSC.

Menurut pendapat Kaplan dan Norton (2000) dapat disimpulkan bahwa BSC dapat diimplementasikan ke dalam berbagai level organisasi, ada lima langkah yang harus dilakukan, yaitu :

Pertama, menetapkan suatu pengukuran kinerja yang berorientasi pada hasil yang menyeimbangkan pencapaian target dari keempat perspektif tersebut. Dalam hal ini diperlukan tiga langkah konkret yaitu (1) mendefinisikan atau menentukan pengukuran yang paling berarti bagi stakeholders yang berfungsi untuk mengarahkan perhatian mereka, (2) penumbuhan komitmen pada perubahan-perubahan dasar dengan melibatkan berbagai pihak dan menerapkan sistem yang "fleksibel" (tidak kaku) serta menentukan arahan yang jelas untuk pelaksanaan, monitoring, pengukuran dan pelaporannya, serta (3) memperhatikan fleksibilitas melalui perhatian bahwa manajemen kinerja adalah proses 
yang hidup, dan mempertahankan keseim-bangan antara pengukuran keuangan dan nonkeuangan.

Kedua, menetapkan akuntabilitas pada semua level organisasi. Akuntabilitas harus dipandang sebagai kunci keberhasilan organisasi, harus menjadi tanggung jawab setiap individu, dan yang lebih penting harus diwujudkan oleh pimpinan organisasi melalui contoh/ teladan.

Ketiga, mengumpulkan, menggunakan, dan menganalisis data yang diperoleh dan menghubungkannya ke dalam proses perencanaan strategik. Data dan informasi yang harus dikumpulkan meliputi data umpan balik (feedback) dari masyarakat, perubahan lingkungan makro, dan data kinerja organisasi. Hasil analisis terhadap data-data tersebut harus pula disampaikan kepada masyarakat sebagai salah satu stakeholders.

Keempat, menghubungkan hasil analisis data dan informasi di atas ke dalam proses penyusunan program kerja berikut penyusunan anggarannya. Dalam hal ini harus dapat ditunjukkan dengan jelas bahwa penyusunan program dan anggaran tersebut adalah dalam rangka mencapai misi organisasi yang telah ditetapkan.

Kelima, membagi peran kepemimpinan. Meskipun pada berbagai level organisasi diperlukan seorang pemimpin yang kuat, tidak berarti bahwa semua pengambilan keputusan harus dimonopoli oleh sang pemimpin. Di sini diperlukan desentralisasi dalam pengambilan keputusan, tetapi dalam koridor peraturan-perundangan yang ada, yang sesungguhnya dimaksudkan untuk dapat segera merespons atau memenuhi kebutuhan masyarakat. Kekhawatiran bahwa bawahan akan melakukan distorsi dalam pengambilan keputusan (karena menyimpang dari kebijakan) harus dapat dicegah melalui proses vision and mission sharing serta pemberdayaan (empowerment) yang telah dilakukan. Untuk dapat memenuhi kebutuhan di level organisasi yang berbeda, maka sebelum digunakan ada beberapa perubahan yang dilakukan dalam konsep BSC. Perubahan yang terjadi antara lain : 1) perubahan framework, yaitu yang menjadi driver dalam BSC untuk level organisasi adalah misi untuk melayani masyarakat, 2) perubahan posisi antara perspektif finansial dan perspektif pelanggan, 3) perspektif customers menjadi perspektif customers \& stakeholders. 4) perubahan perspektif learning dan growth menjadi perspektif employees and organization capacity.

Beberapa syarat agar BSC dapat tercapai efektifitasnya, yaitu sebagai berikut.

1. Ada definisi yang jelas atas tujuan individu, tim, unit organisasi, dan organisasi

2. Memahami hubungan antara proses internal yang bernilai tambah dengan outcome yang dihasilkan.

3. Mengintegrasikan model pengukuran kinerja BSC dalam suatu manajemen strategik, manajemen kinerja, dan sistem penghargaan pegawai. 
Salah satu kunci keberhasilan penerapan BSC menurut 'Reilly (Mattson, 1999: 2) adalah adanya dukungan penuh dari setiap lapisan manajemen yang ada dalam organisasi. BSC tidak hanya berfungsi sebagai laporan, tetapi lebih dari itu, BSC haruslah benar-benar merupakan refleksi dari sebuah strategi perusahaan serta visi organisasi. Bahkan, BSC dapat dipandang sebagai sebuah alat untuk mengkomunikasikan strategi dan visi organisasi perusahaan secara kontinyu. Langkah-langkah tersebut adalah sebagai berikut (Mattson, 1999:2).

a. Memperoleh kesepakatan dan komitmen bersama antara pihak manajemen puncak perusahaan.

b. Mendesain sebuah model (kerangka) BSC, yang memungkinkan perusahaan untuk menentukan beberapa faktor penentu seperti tujuan strategik, perspektif bisnis, indikator-indikator kunci penilaian kinerja.

c. Mengembangkan suatu program pendekatan yang paling tepat digunakan oleh perusahaan sehingga BSC menjadi bagian dari kultur organisasi yang bersangkutan. Konsep scorecard yang dikembangkan dapat dijadikan sebagai salah satu pengendali jika terjadi perubahan kultur dalam perusahaan. Dengan kata lain perusahaan haruslah memperhitungkan apakah penerapan BSC akan mengakibatkan perubahan yang cukup besar dalam organisasi perusahaan.

d. Aspek penggunaan teknologi. Banyak perusahaan sudah mulai menggunakan software komputer dalam menentukan elemen-elemen scorecard dan meng otomatisasikan pendistribusian data ke dalam scorecard. Data-data scorecard, yang berwujud angka-angka pengukuran tersebut, akan di-review dari periode ke periode secara terus-menerus.

\section{KESIMPULAN}

Perbankan berhubungan langsung dengan penyediaan services and goods untuk memenuhi keinginan dan kebutuhan masyarakat. Dalam hal ini masyarakat merupakan pelanggan yang harus dilayani dengan baik sehingga dalam rangka memenuhi customer satisfaction, sangat perlu diterapkan pola pikir terhadap pengelolaan organisasi (good corporate governance) tentang bagaimana meningkatkan kepuasan pelanggan (masyarakat).

Dengan pendekatan BSC, perbankan akan mampu menjelaskan misinya kepada masyarakat dan dapat mengidentifikasi indikator kepuasan masyarakat secara lebih transparan, objektif, dan terukur serta mampu mengidentifikasi proses kerja dan kualitas sumber daya manusia yang dibutuhkannya dalam mencapai misi dan strateginya. Sebaliknya di dalam proses implementasinya, kegiatan yang di lakukan oleh perbankan 
akan dapat menghasilkan suatu sistem manajemen startegik yang berorientasi pada masyarakat.

\section{REFERENSI}

Hastuti, T.D., 2005, Hubungan antara Good Corporate Governance dan Struktur Kepemilikian dengan Kinerja Keuangan (Studi Kasus pada Perusahaan yang Listing di Bursa Efek Jakarta), Simposium Nasional Akuntansi VIII.

Kaplan, Robert S., dan David P. Norton, (2000) Balanced Scorecard, Erlangga, Jakarta.

Mattson, Beth. 199. "Executives Learn How To Keep Score : BSC Gets All Employess Focusting On Vision".

Mulyadi, (2001) "Balanced Scorecard : Alat Manajemen Kontemporer untuk Pelipat Ganda Kinerja Keuangan Perusahaan, Salemba Empat, Jakarta.

Rahmadhani, F., 2008, Analisis Pengaruh Penerapan Corporate Governance dan Growth Opportunity pada Harga Saham Perusahaan dalam Daftar CGPI yang dirilis IICG.

Siallagan, Hamonangan \& Mas'ud Machfoedz. 2006. Mekanisme Corporate Governance, Kualitas Laba dan Nilai Perusahaan. Simposium Nasional Akuntansi IX Padang.

Sutojo, Siswanto \& E. John Aldridge. 2008. Good Corporate Governance : Tata Kelola Perusahaan Yang Sehat. PT. Damar Mulia Pustaka, Jakarta.

Tunggal. Amin Widjaja. 2008. Tata Kelola Perusahaan : Teori dan Kasus. Harvarindo, Jakarta. 